\title{
Психологічна програма розвитку особистісних детермінант вибору ефективних копінг-стратегій учасників операції Об'єднаних Сил на етапі декомпресії
}

\author{
Марія Ярмольчик 1 А \\ А Кафедра військової підготовки Національного авіаційного університету, вул. Медова 1, м. Київ, 03048, Україна
}

Received: June 15, 2021 | Revised: June 25, 2021 | Accepted: June 30, 2021

DOI: $10.33445 /$ sds.2021.11.3.22

\begin{abstract}
Анотація
Мета статті полягає в розкритті особливостей проведення заходів психологічної програми розвитку особистісних детермінант вибору копінг-стратегій. Запропоновано структуру проведення основних етапів психологічної роботи. Проаналізовано особливості проведення занять, основні методи та техніки роботи з учасниками операції об'єднаних сил. У дослідженні використано наступний психологічний інструментарій: арт-терапії: музикотерапія, ізотерапія, пісочна терапія, техніки візуалізації, психоедукація, тренінгові заняття, консультування. Дослідження було проведене з 60 респондентами під час проводження психологічної програми розвитку особистісних детермінант вибору ефективних копінг-стратегій на етапі декомпресії, після тривалого перебували в зоні проведення операції Об'єднаних Сил. Визначено, що опрацьовуючи кожен етап, військовослужбовці проходять комплексне психологічне відновлення, що дає змогу продовжувати проходження військової служби та виконання завдань за призначенням. При проведенні психологічної програми виделено наступні сфери особистості, які відіграють важливу роль у виборі ефективних копінгів: емоційно-регулятивна, цінніснонормативна, особистісно-рефлексивна, соціально-адаптивна. Запропонована програма реалізовувалась через ряд заходів, які проводились з респондентами під час проходження ними декомпресії за встановленим графіком і розпорядком. Запропонована програма активізує особистісні риси військовослужбовців, які виступають ресурсом для вибору копінг-стратегій. Завдяки виявленню особистісних детермінант вибору копінг-стратегій, військовослужбовці можуть частіше використовувати копінги більш ефективні у боротьбі зі стресом, водночас рідше - копінги пасивного пристосування до стресу.
\end{abstract}

Ключові слова: копінг-стратегії, особистісні риси, військовослужбовці, тренінг, психологічна програма.

\section{Постановка проблеми}

Військова психологія, на сьогоднішній день, має ряд завдань, які потребують вирішення, зокрема з'ясування особливостей взаємозв'язку особистісних рис військовослужбовців та копінг-стратегій під час проходження декомпресії. Однак, відсутні концептуальні теоретичні розробки, чіткі базові поняття у галузі дослідження детермінації вибору відповідних копінгів 3 метою продуктивного подолання стресової ситуації та її наслідків.
Військовослужбовці, котрі виконують на сході України свій обов'язок, переживають суттєві внутрішні навантаження, що перевищують можливості людини, руйнують звичне сприйняття і поведінку, часто призводять до небезпечних наслідків, спричиняють розлади адаптації. Останні характеризуються складними психофізіологічними, поведінковими, мотиваційними змінами, погіршенням самопочуття, трансформацією картини світу, когнітивних

\footnotetext{
1 аспірант кафедри авіаційної психології , e-mail: LinkinFan357@ukr.net, ORCID: 0000-0001-9917-0189
} 
стратегій, що відповідно впливає на стосунки, на можливість виконувати поставлені завдання, погіршує боєздатність особового складу.

Окрім розладів спричинених стресовими та травматичними ситуаціями в зоні бойових дій в особового складу в період адаптації до умов мирного життя часто формується вторинний стрес, спричинений нерозумінням стану і потреб військовослужбовців їхніми друзями, котрі не воювали, рідними, бюрократичною системою у медичних закладах, банках тощо. Військові у стані вторинного стресу переживають безсилля, відчай, для цього стану часто характерне “тунельне бачення" ситуації, прагнення помсти кривдникам.

у ситуації, що склалася, особливої актуальності набуває питання психологічної декомпресії особового складу у період відновлення після виведення із зони бойових дій у пункти постійної дислокації. Психологічна декомпресія військовослужбовців - це комплекс заходів (зокрема організація психологічної допомоги), що надаються воїнам, які відбувають у відпустку після виконання бойового завдання. Психологічна декомпресія, як первинний етап реабілітації, $є$ важливим процесом, що забезпечує відновлення психічного та фізичного здоров'я військовослужбовців, які тривалий час перебували в зоні бойових дій. Цей складаний процес включає в себе різні напрями роботи, спрямовані на швидке опрацювання пережитого бойового стресу, забезпечення базових соціально-побутових запитів та медичний огляд військових. Головне завдання - забезпечити максимальне відновлення особового складу

\author{
3 можливістю \\ подальшого \\ виконання \\ бойових завдань.
}

Проведення психологічної декомпресії має на меті відновлення психологічного стану військовослужбовців, 3 можливістю повернення до виконання службових обов'язків. Заходи декомпресії розраховані на 7-10 днів, згідно наказів Міністерства оборони України. Однак, визначений термін $є$ дуже коротким і не дозволяє провести комплексну роботу з військовослужбовцями таким чином, щоб це було ефективно. Психологічне відновлення триває близько 14 - 21 доби. Це період, який необхідний для того, щоб адаптуватись і перелаштуватись 3 бойових умов до мирних. Для того, щоб процес декомпресії був ефективним, необхідно збільшити термін проведення цих заходів, забезпечити необхідне місце для розміщення військовослужбовців. Під час проведення психологічної діагностики слід звернути увагу на підбір інструментарію, взяти до використання методики, які вимірюють рівень стресу. Важливо розуміти, що військовослужбовці після перебування в зоні бойових дій повертаються 3 "бойовим» сприйняттям дійсності. Отриманий військовий досвід має значний комплексний вплив на особистість, що проявляється у: постійній напрузі, наявності прихованих страхів, агресивності та озлобленості до всіх незнайомих і підозрілих людей, страх неприйняття та осуду. Цивільні умови стали незвичними, навіть небезпечними для них. Період декомпресії повинен забезпечити адаптацію до мирного життя, навчити використовувати власні ресурси для того, щоб впоратись з пережитим.

\section{Аналіз останніх досліджень та публікацій}

Результати емпіричного дослідження показали, що військовослужбовці використовують ряд непродуктивних копінгстратегій, що обумовлено особистісними рисами. Такі показники обумовлені бойовими діями, стресовими ситуаціями, постійним психологічним навантаженням.
Для того, щоб ефективно вирішувати стресогенні ситуації та конструктивно діяти в складних, напружених ситуаціях військовослужбовцям необхідно знати власні особливості та вміти використовувати їх при використанні копінг-стратегій. До того ж, досліджувані мають розуміти і знати, що таке 
копінг, які види копінг-стратегій $\epsilon$ і яким чином кожна стратегія допомагає впоратись зі стресом в залежності від ситуації.

Кожен військовослужбовець, за рахунок особистісних рис та характеристик, створює стратегією вирішення стресогенної ситуації, намагається зберегти та захистити власні, суб'єктивно унікальні копінг-ресурси. Подолання ситуації, пов'язаної з бойовими умовами, передбачає інтенсивне застосування різних видів копінг-стратегій. Якщо відбувається “виснаження" або недоступність в актуальному часі одного 3 копінгів, військові можуть, без суттєвих втрат, вдало компенсувати його відсутність іншими, продуктивними копінг-стратегіями, задля позитивного долання стресу.

Копінг-стратегії дають змогу військовослужбовцям виконувати бойові завдання у різних професійних ситуаціях. Кінцевою метою та критерієм ефективності кожного копінгу можна вважати рівень зниження стресогенного тиску ситуації, тобто перехід на нормальний рівень функціонування. Важливо відмітити, що для військовослужбовців $\epsilon$ важливою частота застосування та різноманітність стратегій.

\section{Постановка завдання}

Мета статті - проаналізувати основні етапи психологічної програми розвитку особистісних детермінант вибору ефективних копінг-стратегій на етапі декомпресії, яку проходять учасники операції об'єднаних сил.

\section{Виклад основного матеріалу}

Методологічну основу дослідження становить когнітивна теорія стресу й копінгу (Р. Лазарус, С. Фолкман та інші) та диспозиційна теорія особистості Г.Олпорта.

Емпірична вибірка. Для встановлення взаємозв'язків між особистісними параметрами та копінг-стратегіями було проведено психологічну діагностику 60 учасників операції об'єднаних сил під час проходження декомпресії. Дослідження було проведено 3 дотриманням етичних принципів та за добровільною згодою респондентів. Для досягнення мети статті використано методи аналізу наукової літератури з проблеми; систематизація та узагальнення даних; діагностичні методики; психологічні техніки, тренінги.

При проведенні психологічної програми розвитку особистісних детермінант вибору ефективних копінг-стратегій доцільно виділити наступні сфери особистості, які будуть задіяні під час психологічних тренінгів:

- емоційно-регулятивний: включає регуляцію та оптимізацію емоційного стану.

- ціннісно-нормативний: включає нейтралізацію та реконструкцію негативних поведінкових реакцій 3 виходом 3 дезадаптивної ролі.
- особистісно-рефлексивний: включає формування продуктивних копінг-стратегій.

- соціально-адаптивний: включає адаптацію і соціалізацію особистості.

Вихідні дані психологічної програми:

- тип занять: навчально-формувальні.

- цільова аудиторія занять: військовослужбовці.

- кількість учасників: 4 групи по 15 осіб у кожній (60 осіб). Дві групи експериментальні, дві контрольні. Групи сформовані за показниками копінг-стратегій за результатами попереднього тестування за методиками діагностики копінг-стратегій особистості. Така кількість осіб у групі дозволяє психологу охопити кожного увагою та контролювати психологічний стан.

- час, необхідний для проведення програми: 25 годин, 7 днів, тривалість: в середньому 3-4 години в день.

Такий комплексний підхід до організації психокорекційних заходів сприяє активізації розвитку особистісних рис, які обумовлюють формування продуктивних, ефективних копінг-стратегій.

Необхідне обладнання для проведення тренінгових, психокорекційних занять: простора, світла кімната, для деяких вправ 
спортивний зал, каремати, канцелярське приладдя, пісочниця, фарби, пензлі, метафоричні карти, аудіотехніка.

Запропоновані техніки та вправи $\epsilon$ ефективними для досягнення поставленої мети. Ряд з них було використано автором під час участі у пілотному проекті Міністерства оборони України з психологічної декомпресії. Слід враховувати, що будь яка психологічна діяльність під час декомпресії має ґрунтуватись на наступних принципах, представлених на рис. 1.

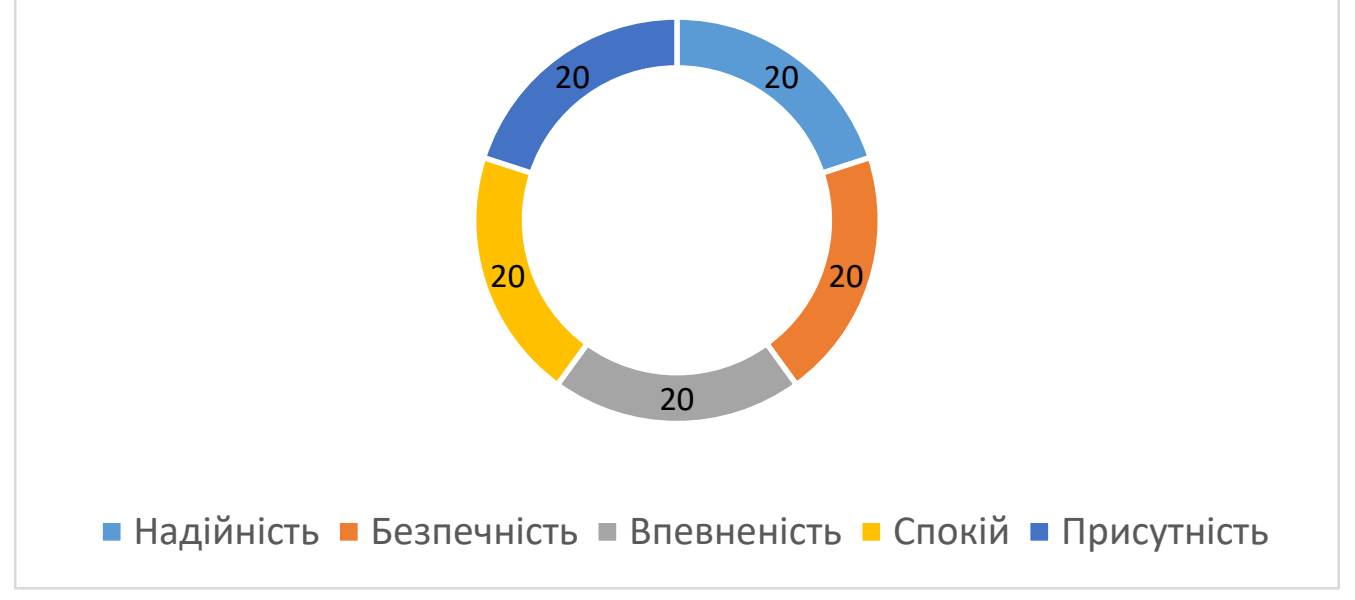

Рисунок 1 - Принципи надання психологічної безпеки

Військовослужбовці мають відчувати, що психологи надійні і їм можна довіряти. Те саме, стосується і середовища, у якому вони знаходяться на декомпресії. Місце має бути безпечним, не викликати почуття страху і підозри. Вони мають бути впевнені в тому, що роблять і в людях, які працюють з ними. При цьому, атмосфера повинна бути спокійною і затишною, а психологи знаходитись завжди поруч, готові прийти на допомогу. Таким чином забезпечується відчуття присутності.

Структурна організація занять побудована із збереженням всіх ознак тренінгових форм роботи (принципи функціонування групи, спрямованість на психологічну допомогу учасникам групи у самопізнанні, просторова організація, вербалізована рефлексія, об'єктивізація почуттів і емоцій, клімат психологічної довіри і близькості та ін.). Враховані основоположні принципи забезпечення ефективної роботи тренінгової групи: активність, дослідницька позиція, усвідомлення або об'єктивування, партнерське спілкування.

У табл. 1 наведено структуру психологічної програми для військовослужбовців в ході проведення психокорекційних заходів.

За даним табл. 1 можна відзначити, що кожен блок включає ряд практичних вправ і технік, які $\epsilon$ ефективними та важливим у досягненні визначеної мети. Ряд технік мають профілактичну складову попередження негативних психосоматичних та фізіологічних симптомів у військовослужбовців, забезпечують підвищення психологічної стійкості до негативних впливів.

Обов'язково, на початку тренінгу “Формування продуктивних копінгстратегій", слід оцінювати психологічний стан групи, за необхідності починати з дихальних, медитативних технік, якщо військовослужбовці неналаштовані на продуктивну роботу. Якщо група готова до заняття, слід озвучити мету заняття, таймінг, порядок роботи. Це потрібно для зниження тривоги та страху перед невідомими, адже після бойових дій у багатьох військових підвищена тривожність. Визначено, що групова форма роботи полегшує вираження емоцій та допомагає освоїти нові моделі поведінки. 
Таблиця 1 - Структура психологічної програми

\begin{tabular}{|c|c|c|}
\hline Назва блоку & Заняття & $\begin{array}{c}\text { Особистісні риси, які } \\
\text { задіяні }\end{array}$ \\
\hline Початок тренінгу & $\begin{array}{c}\text { 1.Вступне слово психолога. } \\
\text { 2.Ознайомлення учасників з метою, завданнями } \\
\text { тренінгу. } \\
\text { 3. Вправи на створення робочої атмосфери в групі: } \\
\text { “Привітання”, “Я налаштований на...”, “Контакт із } \\
\text { групою”, “Правила нашої групи”. } \\
\text { 4. Збір очікувань від учасників тренінгу: вправа } \\
\text { “Автобусна зупинка”, Вправа на розвиток довіри } \\
\text { “Поводир” }\end{array}$ & $\begin{array}{c}\text { Комунікабельність, } \\
\text { відкритість, } \\
\text { врівноваженість, } \\
\text { довірливість, сміливість, } \\
\text { сором'язливість }\end{array}$ \\
\hline $\begin{array}{c}\text { Розвиток } \\
\text { самосприйняття та } \\
\text { рефлексії учасників } \\
\text { групи }\end{array}$ & $\begin{array}{c}\text { Вправи: “Я в умовах стресогенної ситуації”. } \\
\text { Практичні вправи: “Вияви агресію, відступи від } \\
\text { агресії”, “Шкалування емоцій” } \\
\text { Ряд когнітивних вправ. }\end{array}$ & $\begin{array}{c}\text { Розслабленість, чутливість, } \\
\text { моральна нормативність, } \\
\text { агресивність, тривожність, } \\
\text { нонконформізм, } \\
\text { конформізм } \\
\end{array}$ \\
\hline $\begin{array}{l}\text { Розвиток емоційної, } \\
\text { вольової регуляції }\end{array}$ & $\begin{array}{c}\text { Використання арт-терапії: музикотерапія, } \\
\text { ізотерапія, пісочна терапія. Техніки візуалізації. } \\
\text { Агресія. Регуляція злості. Тривожні розлади. } \\
\text { Розпізнання та самоопанування. Техніки } \\
\text { зниження агресії та тривожності, як особистісних } \\
\text { рис. }\end{array}$ & $\begin{array}{c}\text { Емоційна стійкість, } \\
\text { емоційна лабільність, } \\
\text { врівноваженість, } \\
\text { експресивність, } \\
\text { самоконтроль }\end{array}$ \\
\hline $\begin{array}{l}\text { Опрацювання } \\
\text { негативних } \\
\text { поведінкових } \\
\text { реакцій }\end{array}$ & $\begin{array}{c}\text { Казкотерапія, арт-терапія, метафоричні карти. } \\
\text { Рольові ігри. }\end{array}$ & $\begin{array}{l}\text { Підпорядкованість, } \\
\text { домінантність, } \\
\text { прямолінійність, } \\
\text { дипломатичність, } \\
\text { чутливість, }\end{array}$ \\
\hline $\begin{array}{c}\text { Формування } \\
\text { продуктивних } \\
\text { копінг-стратегій }\end{array}$ & $\begin{array}{c}\text { Проведення занять на формування ефективних } \\
\text { копінг-стратегій }\end{array}$ & $\begin{array}{c}\text { Самоконтроль, відкритість, } \\
\text { практичність, емоційна } \\
\text { стійкість, } \\
\text { комунікабельність } \\
\end{array}$ \\
\hline $\begin{array}{l}\text { Розвиток навичок } \\
\text { самоконтролю і } \\
\text { самоефективності }\end{array}$ & $\begin{array}{c}\text { Вправи: “Хто я”, рольові ігри. } \\
\text { Вправи на розвиток особистісного контролю над } \\
\text { ситуацією. } \\
\end{array}$ & $\begin{array}{c}\text { Самоконтроль, } \\
\text { стриманість, } \\
\text { експресивність } \\
\end{array}$ \\
\hline $\begin{array}{c}\text { Підведення } \\
\text { підсумків та } \\
\text { обговорення } \\
\text { результатів тренінгу }\end{array}$ & $\begin{array}{c}\text { Виконання вправ: “Я розумію, я відчуваю”, “Я } \\
\text { залишаю собі...”, “Я володію, ти володієш...”, } \\
\text { “Особисто для мене, саморегуляція це...”, “Карта } \\
\text { групи” Постановка цілей на майбутнє. }\end{array}$ & $\begin{array}{c}\text { Відкритість, } \\
\text { врівноваженість, } \\
\text { дипломатичність, } \\
\text { практичність, мрійливість, } \\
\text { спокій, розслабленість }\end{array}$ \\
\hline
\end{tabular}

Кожне заняття варто починати з пояснення відповідної стратегії-психоедукації. Важливо адаптувати мову під рівень військових, не нагромаджувати незрозумілу термінологію та не говорити занадто голосно. Завдання психоедукації - передати інформацію та надати пояснення про дану проблему тощо.

Загалом, слід відзначити, що поняття копінг-стратегій $\epsilon$ мало відоме серед військових, то ж корисно буде детально пояснити суть копінгів, їх значення у подоланні стресу та важливість обрання продуктивної стратегії.

Кожне наступне заняття починається 3 відтворення елементів попереднього 3 метою кращого засвоєння матеріалу. Слід зазначити, що військовослужбовці - це специфічна вибірка, тому слід враховувати їхні психологічні особливості.

Далі переходимо до основної частини 
заняття, яка включає програвання ситуацій, виконання практичних вправ, що потребують використання відповідної копінг-стратегії. При цьому ситуації досить нейтральні, побутового характеру. Розігрувати ситуації з військової тематики досить ризиковано, оскільки можливі травматичні спогади у вигляді флешбеків. При цьому слід уважно спостерігати за учасниками, оскільки декому можливо необхідна перерва.

\section{Висновки}

у цілому можна підсумувати, що психологічна програма має враховувати наступні сфери особистості:

1. Емоційна: зниження психологічної напруги, формування навичок емоційної стійкості, врівноваженості; розвиток емоційного самоконтролю, правильної ідентифікації своїх почуттів і переживань.

2. Комунікативна: забезпечення необхідної комунікації у підрозділі; налагодження спілкування 3 сім'єю, формування комунікативних навичок.

3. Поведінково-діяльнісна: формування навичок групової взаємодії, підвищення навичок усвідомлення власних дій, формування продуктивної стратегії поведінки в стресовій ситуації, навчання вибору ефективних копінгів.

4. Когнітивна: усвідомлення власних цілей, моделей поведінки (в тому числі і копінг-стратегій).

5. Свідомість: опрацювання негативних спогадів, відновлення самоусвідомлення за
Якщо спостерігається втома хоч в одного військовослужбовця, слід дати паузу групі. Під час заняття в доступності має бути достатня кількість води. У ході проведення занять доцільно використовувати відеоматеріали за тематикою. На при кінці заняття слід підвести підсумки та залишити час для запитань-відповідей. Оскільки групи не великі, $€$ можливість вислухати враження кожного з військовослужбовців-учасників.

допомогою використання психологічних вправ.

6. Ставлення до особистості: формування емпатійності, розуміння, сприйняття інших.

Програма розвитку особистісних детермінант вибору ефективних копінгстратегій учасниками операції об'єднаних сил спрямована на шість основних блоків, які представляють різні сторони особистості, відповідно до мети дослідження та поставлених завдань. У ході проходження всіх етапів програми, респонденти набули психологічної готовності до «повернення» в мирне життя, здатні активно працювати над собою, навчились розрізняти продуктивні та непродуктивні копінг-стратегії, усвідомили та навчились визначати власні копінги, оволоділи новими знаннями, уміннями й навичками вибору ефективних копінгстратегій за рахунок особистісних рис. Програма реалізована 3 урахування особистісних диспозицій досліджуваних: кардинальних, центральних і вторинних.

\section{Список використаних джерел}

1. Alex Kocha, Vincent Yzerbytb,Andrea Abelec, Naomi Ellemersd, Susan T.Fiske (2021). Comparing models across interpersonal, intragroup, intergroup, several-group, and many-group contexts. Advances in Experimental Social Psychology, 64, 1-68. DOI: 10.1016/bs.aesp.2020.11.001

2. Brew, F.P., Cairns, D.R. (2004) Do culture or situational constraints determine choice of direct or indirect styles in intercultural workplace conflicts? International Journal of
Intercultural Relations, 28 (5), pp. 331-352. http://doi.org/10.1016/j.ijintrel.2004.09.001 3. Chen, G.-M. (1992) Communication Adaptability and Interaction Involvement as Predictors of Cross-Cultural Adjustment. Communication Research Reports, 9 (1), pp. 33-41. DOI: 10.1080/08824099209359895

4. Billings A.G., Moos R.H. (2013). Coping, stress and social resources among adults with unipolar depression. J. Pers and Soc. Psychol. Vol. 46, pp.877-891. 
5. Clark K., and C. Bormann, Cropanzano, R., James K. (1995) Validation evidence for three coping measures. Journal of Personality Assessment. 65, 434-455.

6. David M. Fisher, Rebekah D. Law (2020). How to Choose a Measure of Resilience: An Organizing Framework for Resilience Measurement. Applied psychology-an international review-psychologie appliqueerevue international. 643-673. DOI: 10.1111/apps.12243

7. Диагностика в арт-терапии. Метод «Мандала» / под ред. А. И. Копытина. СПб. : Речь, 2002. 80 c.
8. Кокоренко В. Л. Арт-технологии в подготовке специалистов помогающих профессий / В. Л. Кокоренко. - СПб. : Речь, 2005. Кокоренко В. Л. Арт-технологии в подготовке специалистов помогающих профессий: [коллажи, маски, куклы]. СПб. : Речь, 2005. 99с.

9. Комар Зоран. Психологічна стійкість воїна: підручник для військових психологів. К: Stabilization Support Services. 2017. 185c.

10. Копытин А. И. Техники аналитической арттерапии. СПб. : Речь, 2007. 186 с.

11. Лебедева Л. Д. Практика арт-терапии: подходы, диагностика, система занятий. СПб. : Речь, 2003. 256 с.

\title{
Психологическая программа развития личностных детерминант выбора эффективных копинг-стратегий участников операции объединенных сил на этапе декомпрессии
}

\author{
Мария Ярмольчик ${ }^{1 \text { A }}$ \\ ${ }^{1}$ аспирант кафедры авиационной психологии, e-mail: LinkinFan357@ukr.net, ORCID: 0000-0001-9917-0189 \\ А Кафедра военной подготовки Национального авиационного университета, ул. Медовая 1, г. Киев, 03048, Украина
}

\begin{abstract}
Аннотация
Цель статьи заключается в раскрытии особенностей проведения мероприятий психологической программы личностных детерминант выбора копинг-стратегий. Предложена структура проведения основных этапов психологической работы. Проанализированы особенности проведения занятий, основные методы и техники работы с участниками операции объединенных сил. В исследовании использованы следующий психологический инструментарий: арт-терапии: музыкотерапия, изотерапия, песочная терапия, техники визуализации, психоедукация, тренинговые занятия, консультирование. Исследование было проведено с 60 респондентами во время провождения психологической программы личностных детерминант выбора эффективных копингстратегий на этапе декомпрессии, после длительного находились в зоне проведения операции Объединенных Сил. Определено, что, прорабатывая каждый этап, военнослужащие проходят комплексное психологическое восстановление, что позволяет продолжать прохождения военной службы и выполнение задач по назначению. При проведении психологической программы выделено следующие сферы личности, которые играют важную роль в выборе эффективных копинг: эмоционально-регулятивная, ценностно-нормативная, личностно-рефлексивная, социально-адаптивная. Предложенная программа реализовывалась через ряд мероприятий, которые проводились с респондентами во время прохождения ими декомпрессии по установленному графику и распорядку. Предложенная программа активизирует личностные черты военнослужащих, выступающих ресурсом для выбора копинг-стратегий. Благодаря выявлению личностных детерминант выбора копинг-стратегий, военнослужащие могут чаще использовать копинг более эффективные в борьбе со стрессом, одновременно реже - копинг пассивного приспособления к стрессу.
\end{abstract}


Ключевые слова: копинг-стратегии, личностные черты, военнослужащие, тренинг, психологическая программа.

\title{
Psychological program of development of personal determinants of choice of effective coping strategies of participants of the joint force operations
}

\author{
Maria Yarmolchyk ${ }^{1 \mathrm{~A}}$ \\ ${ }^{1}$ PhD student, e-mail: LinkinFan357@ukr.net, ORCID: 0000-0001-9917-0189 \\ A National Aviation University, 1, Medova st., Kyiv, 03048, Ukraine
}

\begin{abstract}
Purpose of the article is to reveal the features of the psychological program for the development of personal determinants of the choice of coping strategies. The structure of carrying out the basic stages of psychological work is offered. Peculiarities of conducting classes, basic methods and techniques of working with participants of the joint forces operation are analyzed. The following psychological tools were used in the study: art therapy: music therapy, isotherapy, sand therapy, visualization techniques, psychoeducation, training, counseling. The study was conducted with 60 respondents during a psychological program for the development of personal determinants of the choice of effective coping strategies at the stage of decompression, after a long stay in the area of Operation Joint Forces. It is determined that during each stage, servicemen undergo a comprehensive psychological recovery, which allows them to continue military service and perform assigned tasks. During the psychological program, the following areas of personality are identified that play an important role in choosing effective coping: emotional-regulatory, value-normative, personality-reflexive. The proposed program was implemented through a number of activities that were carried out with the respondents during their decompression according to the established schedule and schedule. The proposed program activates the personal traits of servicemen, who act as a resource for choosing coping strategies. By identifying the personal determinants of coping strategy choices, military personnel are more likely to use copings that are more effective in combating stress, while less likely to use copings of passive stress adaptation.
\end{abstract}

Keywords: coping strategies, personality traits, military personnel, training, psychological program.

\section{References}

1. Alex Kocha, Vincent Yzerbytb,Andrea Abelec, Naomi Ellemersd, Susan T.Fiske (2021). Comparing models across interpersonal, intragroup, intergroup, several-group, and many-group contexts. Advances in Experimental Social Psychology, 64, 1-68. DOI: 10.1016/bs.aesp.2020.11.001

2. Brew, F.P., Cairns, D.R. (2004) Do culture or situational constraints determine choice of direct or indirect styles in intercultural workplace conflicts? International Journal of Intercultural Relations, 28 (5), pp. 331-352. http://doi.org/10.1016/j.ijintrel.2004.09.001
3. Chen, G.-M. (1992) Communication Adaptability and Interaction Involvement as Predictors of Cross-Cultural Adjustment. Communication Research Reports, 9 (1), pp. 33-41. DOI: 10.1080/08824099209359895

4. Billings A.G., Moos R.H. (2013). Coping, stress and social resources among adults with unipolar depression. J. Pers and Soc. Psychol. Vol. 46, pp.877-891.

5. Clark K., and C. Bormann, Cropanzano, R., James K. (1995) Validation evidence for three coping measures. Journal of Personality Assessment. 65, 434-455. 
6. David M. Fisher, Rebekah D. Law (2020). How to Choose a Measure of Resilience: An Organizing Framework for Resilience Measurement. Applied psychology-an international review-psychologie appliqueerevue international. 643-673. DOI: 10.1111/apps.12243

7. Dyahnostyka v art-terapyy. Metod «Mandala» / pod red. A. Y. Kopytyna. -SPb. : Rech, 2002. $80 \mathrm{~s}$.

8. Kokorenko V. L. Art-tekhnolohyy v podhotovke spetsyalystov pomohaiushchykh professyi / V. L. Kokorenko. - SPb.: Rech,
2005. Kokorenko V. L. Art-tekhnolohyy v podhotovke spetsyalystov pomohaiushchykh professyi: [kollazhy, masky, kukli]. SPb. : Rech, 2005. 99 s.

9. Komar Zoran. Psykholohichna stiikist voina: pidruchnyk dlia viiskovykh psykholohiv. K: Stabilization Support Services. 2017. 185s.

10. Kopytyn A.Y. Tekhnyky analytycheskoi artterapyy. SPb. : Rech, 2007. $186 \mathrm{~s}$.

11. Lebedeva L. D. Praktyka art-terapyy: podkhodb, dyahnostyka, systema zaniatyi. SPb. : Rech, 2003. $256 \mathrm{~s}$. 